\title{
Physiotherapy approaches applied to patients with fibromyalgia: systematic review of clinical trials
}

\author{
Yago Tavares Pinheiro', Marcelo Cardoso de Souza',2, Thiago Anderson Brito de Araújo ${ }^{3}$, Rodrigo Scattone da Silva', \\ Caio Alano de Almeida Lins ${ }^{1}$
}

\begin{abstract}
Background: Due to the complexity of the fibromyalgic patient's condition, therapeutic resources are being recruited to manage the signs and symptoms of patients with this disorder. However, the range of options offered hinders the decision-making of therapists, since the approaches are often heterogeneous. Objectives: The objective was to characterize publications on the effects of physical therapy in patients with fibromyalgia and to investigate the main effects of these therapies. Methods: A search was performed between November 2017 and March 2018 by articles published in the databases PEDro, PUBMED and SciELO from the combination of the descriptors "Fibromyalgia" and "Physical Therapy Modalities". We included clinical trials involving subjects with fibromyalgia and that approached some physiotherapeutic technique in at least one of the intervention groups. Results: A total of 861 studies were identified. Of these, $\mathbf{2 8}$ met the eligibility criteria. In addition, 02 studies were included from secondary sources. There was a predominance of studies published in the last nine years, in which the evaluation instruments of the type questionnaires, inventories and scales were used mainly. In addition, it was possible to observe an improvement in outcomes such as pain, quality of life, sleep, general health, functional capacity, balance, anxiety and depression in patients with Fibromyalgia submitted to techniques such as kinesiotherapy, hydrotherapy, electrothermo-therapy, bandages, among others. Conclusions: The evidences found support the use of physiotherapy as a therapeutic resource for patients with Fibromyalgia, since the techniques studied were beneficial in almost all cases. Record PROSPERO: CRD42018087432.
\end{abstract}

Keywords: Fibromyalgia; Therapy; Physiotherapy techniques.

\section{INTRODUCTION}

Fibromyalgia (FM) is described as a musculoskeletal syndrome, with a chronic character and partially clarified etiopathogenesis. It is characterized primarily by the amplification of the pain sensation, which diffuses throughout the body $y^{(1,2)}$. The term that is currently used was first suggested in 1976 by Hench and later recognized after the publication of the study by Yunus et al. ${ }^{(3)}$, who proposed a new model for the pathogenesis of the disease, as well as identified and described its clinical pattern ${ }^{(4)}$.

The prevalence of the syndrome worldwide varies between 0.2 and $6.6 \%$, a number that is higher than those observed in 2006, which varied between 0.7 and $4.4 \%$, mainly in women in the $35-44$ years $^{(5-7)}$.

Although it is a common rheumatic disease in the population, its diagnosis has been a challenge for professionals due to the absence of objective anatomical and / or laboratory markers. In order to reduce subjectivity and increase diagnostic accuracy, the American College of Rheumatology (ACR) published in 1990 the classification criteria currently accepted ${ }^{(8)}$.

In general, the diagnosis is directed through a clinical evaluation that should analyze the presence of signs and symptoms such as muscle spasms, muscle weakness, morning stiffness, anxiety and the presence of at least 11 of the 18 tender points scattered around the body. In addition, FM is closely related to changes in sleep, fatigue, weight loss, headache and depression ${ }^{(8-10)}$.

Given its complexity, new therapeutic modalities are being requested for the management of the disease. As an example, Physiotherapy arises with specific techniques that are proposed to intervene in the symptomatology of the disease, and can have effects on the quality of life of the subjects ${ }^{(11)}$. However, the availability of a large set of therapeutic proposals may interfere with the professional decision making process, at the same time it raises doubts

Corresponding author: Caio Alano de Almeida Lins. Address: Vila Trairí, CEP 59200-000, Santa Cruz, Rio Grande do Norte, Brazil. E-mail: caiouzl@hotmail.com. Phone: +55 (084) 9 9681-0444

${ }^{1}$ Programa de Pós-graduação em Ciências da Reabilitação, Faculdade de Ciências da Saúde do Trairí, Universidade Federal do Rio Grande do Norte, Santa Cruz, Rio Grande do Norte, Brasil.

Full list of author information is available at the end of the article.

Financial support: nothing to declare

Submission date 08 August 2018; Acceptance 19 September 2018; Publication date 11 October 2018 
about the possibility of bringing together the results of these interventions, which are often heterogeneous in relation to duration, goals, configuration, format, therapeutic and professional components involved ${ }^{(12,13)}$.

Although the considerable number of studies evaluating different physiotherapeutic treatments for FM, it is necessary to update these studies in order to identify possible alterations in the findings reported in the literature or to modify the quality of the published evidence, thus guaranteeing a better reliability of the results. Thus, the objective of this systematic review is to characterize the studies that evaluated the effects of physical therapy in patients with FM and to investigate the most significant results of these approaches.

\section{REVIEW}

\section{Methodological aspects}

The present study is a systematic review of the literature published in PROSPERO under protocol CRD42018087432, based on clinical trials published in the databases Physiotherapy Evidence Database (PEDro), United States National Library of Medicine (PUBMED) and Scientific Electronic Library Online (ScieLO). The search was conducted between November 2017 and March 2018, from the free combination of the DeCS "Fibromyalgia" and "Physical Therapy Modalities".

The following inclusion criteria were established for the purpose of the search: a clinical trial, a sample composed of subjects diagnosed with FM and who approached a physiotherapeutic technique in at least one of the intervention groups. We excluded studies that did not address physiotherapeutic techniques.

The search and selection of studies was performed by two independent researchers. After the duplicates were excluded, both researchers proceeded to read the titles and summaries of the studies identified in the databases, and all those that fulfilled the inclusion criteria were obtained in their entirety. In the presence of disagreement a third researcher was consulted to reach a consensus on the inclusion or exclusion of the study (Figure 1).With the integrated data, the results were interpreted and arranged in a descriptive way and in tables with the intention of enabling the applicability of the final product of this review (Table 1).

\section{Main results and discussion}

The search strategy resulted in a total of 861 documents identified (PUBMED $=817$, SciELO $=20$ and PEDro $=24$ ). After applying the inclusion criteria and a detailed analysis, 28 articles fit the criteria of the research eligibility. Two studies were included from other sources. During the first filtering, the main reason for exclusion was due to the methodological design. One study ${ }^{(13)}$ was excluded from one database because of indexation duplicity. After reading in full, two studies were excluded ${ }^{(14,15)}$ because they did not address any

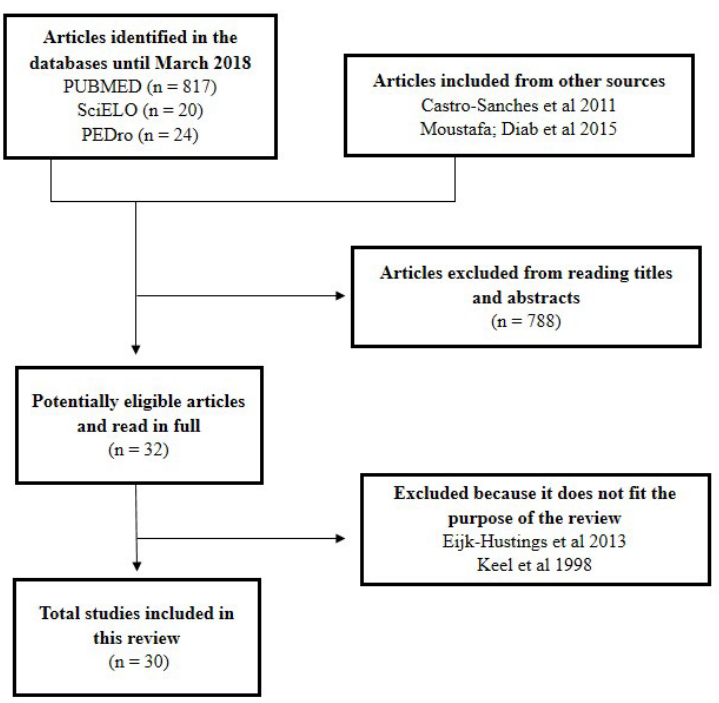

Figure 1. Flowchart of the search and selection of the studies.

physiotherapeutic technique. Figure 1 shows the flowchart of the study selection.

As regards the characterization of included studies, it can be observed that $75 \%(n=21)$ were published in the last 9 years (2008-2017), 21.4\% ( $n=6)$ between 2006 and 2001 and 1 in the 1992, corresponding to $3.6 \%$ of the total sample. In addition, there were predominant publications in English (75\%), followed by Portuguese (21.4\%) and Spanish (3.6\%).

The studies included a total of 1,629 subjects with fibromyalgia, mostly women aged 40 years or older, divided into intervention and control groups, ranging from 10 to 175 volunteers in each study.

Regarding the outcomes, pain was the variable most analyzed by the researchers, being present in $82.1 \%$ of the publications. In addition, it was frequent to include results related to quality of life $(42.8 \%)$, anxiety, depression, and $\operatorname{mood}(35.7 \%)$, sleep and fatigue (42.8\%), general health status (25\%), morning flexibility and stiffness (21.4\%), and balance and muscle strength were among the least investigated (11.2\%) Other results such as: patient satisfaction, number of medications ingested per day, frequency of physical activity and heart rate variability were also studied.

As evaluation instruments, the great use of questionnaires, scales and / or inventories was highlighted. From the total of studies, $85.7 \%$ used some such tool to measure the outcomes. In general, the Fibromyalgia Impact Questionnaire (FIQ), Visual Analogue Scale (VAS), SF-36 quality of life questionnaire and the Beck Depression Inventory were the most used.

Finally, regarding physiotherapeutic interventions, kinesiotherapy (relaxation, stretching, strengthening and aerobic exercises) stood out as the most used approach in the studies, being present in at least one intervention group in $71.4 \%$ of the studies. Also noteworthy is the extensive investigation of hydrotherapy (28.5\%) and electrothermotrophotometric 
Table 1. Summary guide of studies included in this review.

\begin{tabular}{|c|c|c|c|c|c|}
\hline Study & Sample & Groups & Outcomes analyzed & Evaluation instruments & Results \\
\hline $\begin{array}{l}\text { CASTRO SANCHEZ et al. } \\
\text { (2017) }\end{array}$ & 64 & Dry needle vs. Cross ribbon & $\begin{array}{l}\text { Myofascial triggers, spine } \\
\text { mobility }\end{array}$ & $\begin{array}{l}\text { Algometer, VAS, Spinal } \\
\text { Mouse }\end{array}$ & $\begin{array}{l}\text { Dry needles: } \downarrow \text { pain in } \mathrm{mm} \text {. } \\
\text { thoracic and lumbar. Dry } \\
\text { needles and cross-tape: } \\
\text { similar effect on spinal } \\
\text { mobility }\end{array}$ \\
\hline COPPIETERS et al. (2016) & 59 & $\begin{array}{l}\text { Relaxation vs. cognitive } \\
\text { stress }\end{array}$ & Pain & VAS & $\begin{array}{l}\text { A simple relaxation session } \\
\text { as well as cognitive stress } \\
\text { has a negative acute effect } \\
\text { on pain modulation }\end{array}$ \\
\hline LARSON et al. (2015) & 130 & Relaxation vs. resistance & $\begin{array}{l}\text { Strength, impact of } \\
\text { FM, pain, quality of life, } \\
\text { functional capacity, level of } \\
\text { fear and avoidance, overall } \\
\text { impression }\end{array}$ & $\begin{array}{l}\text { Isokinetic dynamometer, } \\
\text { FIQ, VAS, SF-36, WT6, } \\
\text { CPAQ, FABQ, PGIC, } \\
\text { disability related to pain }\end{array}$ & $\begin{array}{l}\text { Progressive resistance } \\
\text { exercise centered in person } \\
\text { is viable, } \uparrow \text { muscular } \\
\text { strength, state of health, } \\
\downarrow \text { pain }\end{array}$ \\
\hline GAVI et al. (2014) & 80 & Strengthening vs. Flexibility & $\begin{array}{l}\text { Physical fitness, pain, } \\
\text { function, quality of life, } \\
\text { mood, heart rate }\end{array}$ & $\begin{array}{l}\text { Dynamometer, tests: } \\
\text { treadmill, MRT1, sit and } \\
\text { reach, VAS, SF-36, FIQ, } \\
\text { IDATE, electrocardiogram }\end{array}$ & $\begin{array}{l}\text { Strengthening is better } \\
\text { than flexibility exercises for } \\
\downarrow \text { pain } \uparrow \text { force. Stretching } \\
\text { improved anxiety. Both } \\
\text { improved the quality of life }\end{array}$ \\
\hline SAÑUDO et al. (2013) & 46 & $\begin{array}{l}\text { WBV vs. exercises vs. usual } \\
\text { medical care }\end{array}$ & $\begin{array}{l}\text { Balance, strength of lower } \\
\text { limbs }\end{array}$ & Biodex F1c, T-FORCE & $\begin{array}{l}\text { Exercises and body } \\
\text { vibration throughout the } \\
\text { body } \uparrow \text { balance }\end{array}$ \\
\hline $\begin{array}{l}\text { CARBONARIO et al. } \\
\text { (2013) }\end{array}$ & 28 & $\begin{array}{l}\text { Education + exercises } \\
+ \text { TENS vs. education + } \\
\text { exercises }\end{array}$ & Pain, impact of FM & VAS, painmeter, FIQ & $\begin{array}{l}\text { Education }+ \text { exercises }+ \\
\text { TENS: } \downarrow \text { pain, anxiety, } \\
\text { fatigue, stiffness, } \uparrow \text { ability } \\
\text { to work }\end{array}$ \\
\hline $\begin{array}{l}\text { LÓPEZ-RODRÍGUEZ et al. } \\
\text { (2012) }\end{array}$ & 70 & $\begin{array}{l}\text { Stretching vs. biodance in } \\
\text { aquatic environment }\end{array}$ & $\begin{array}{l}\text { Pain, impact of FM and } \\
\text { depression }\end{array}$ & $\begin{array}{l}\text { Questionnairies McGill- } \\
\text { Melzack, painmeter, VAS, } \\
\text { FIQ, Beck Inventory }\end{array}$ & $\begin{array}{l}\text { Aquatic biodance: } \downarrow \text { pain, } \\
\uparrow \text { quality of life }\end{array}$ \\
\hline SAÑUDO et al. (2011) & 42 & $\begin{array}{l}\text { Aerobic + strength + } \\
\text { flexibility vs. usual care }\end{array}$ & $\begin{array}{l}\text { Impact of FM, depression, } \\
\text { quality of life, pain }\end{array}$ & $\begin{array}{l}\text { FIQ, Inventory of } \\
\text { depression, SF-36, VSA }\end{array}$ & $\begin{array}{l}\text { Strengthening + flexibility } \\
+ \text { aerobic: } \uparrow \text { state of } \\
\text { psychological health and } \\
\text { quality of life }\end{array}$ \\
\hline $\begin{array}{l}\text { MANNERKORPI et al. } \\
(2010)\end{array}$ & 67 & $\begin{array}{l}\text { Nordic walking vs. low } \\
\text { intensity walking }\end{array}$ & $\begin{array}{l}\text { Functional capacity, impact } \\
\text { of FM, cardiovascular } \\
\text { function, exertion, fatigue, } \\
\text { physical activity, anxiety, } \\
\text { depression, muscular } \\
\text { sensitivity }\end{array}$ & $\begin{array}{l}\text { TC6', FIQ, cycle ergometer, } \\
\text { Borg, telemetry, MFI, LTPAI, } \\
\text { HADS, algometer }\end{array}$ & $\begin{array}{l}\text { Nordic walking is feasible, } \\
\uparrow \text { functional capacity, } \downarrow \\
\text { physical limitations }\end{array}$ \\
\hline GUSI et al. (2010) & 41 & WVB vs. control & Balance & Biodex & $\begin{array}{l}\text { Vibration } \uparrow \text { dynamic } \\
\text { balance }\end{array}$ \\
\hline TARGINO et al. (2010) & 58 & $\begin{array}{l}\text { Acupuncture }+ \text { standard } \\
\text { care vs. standard care }\end{array}$ & $\begin{array}{l}\text { Pain, myofascial trigger } \\
\text { points, quality of life }\end{array}$ & VAS, algometer, SF-36 & $\begin{array}{l}\text { Acupuncture } \downarrow \text { pain, } \uparrow \\
\text { quality of life }\end{array}$ \\
\hline FREGNI et al. (2006) & 32 & $\begin{array}{l}\text { simulated tDCS vs. tDCS } \\
\text { active primary motor } \\
\text { cortex vs. tDCS active left } \\
\text { DLPFC }\end{array}$ & $\begin{array}{l}\text { Pain, FM impact, quality } \\
\text { of life, overall impression, } \\
\text { depression, cognition }\end{array}$ & $\begin{array}{l}\text { VAS, FIQ, SF-36, CGI, PGA, } \\
\text { Beck Depression Inventory, } \\
\text { MMSE }\end{array}$ & $\begin{array}{l}\text { tDCS } \downarrow \text { pain and improves } \\
\text { muscle strength }\end{array}$ \\
\hline CEDRASCHI et al. (2004) & 164 & $\begin{array}{l}\text { Self-management vs. } \\
\text { health education }\end{array}$ & $\begin{array}{l}\text { Impact of FM, quality of } \\
\text { life, pain, satisfaction }\end{array}$ & $\begin{array}{l}\text { FIQ, PGWB, SF-36, RPS, } \\
\text { scale of Likert }\end{array}$ & $\begin{array}{l}\text { Self-management }+ \text { health } \\
\text { education } \uparrow \text { quality of life } \\
\text { and satisfaction }\end{array}$ \\
\hline
\end{tabular}

Note: VAS: Visual Analogic Scale; FIQ: Fibromyalgia Impact Questionnaire; SF-36: Short Form Health Survey; WT6: 6-minute Walk Test; CPAC: Chronic Pain Acceptance Questionnaire; FABC: Fear Avoidance Beliefs Questionnaire; PGIC: Patient Global Impression of Change; MRT1: 1 maximum repetition test; IDATE - Inventário de Ansiedade Traço-Estado; WBV: Whole Body Vibration; TENS: Transcutaneous Electrical Nerve Stimulation; FM: Fibromyalgia; MFI - Multidimensional Fatigue Inventory; LTPAI: Leisure Time Physical Activity Instrument; HADS: Hospital Anxiety and Depression Scale; CGI: Clinical Global Impression; PGA: Patient Global Assessment; MMSE: Mini Mental State Examination; PGWB: Psychological General Well-Being; RPS: Regional Pain Score; NHP: Nottingham Health Profile; MOS: Medical Outcome Study. 
Table 1. Continued...

\begin{tabular}{|c|c|c|c|c|c|}
\hline Study & Sample & Groups & Outcomes analyzed & Evaluation instruments & Results \\
\hline HAKKINEN et al. (2001) & 21 & $\begin{array}{l}\text { Strength vs. no training vs. } \\
\text { healthy with training }\end{array}$ & $\begin{array}{l}\text { Strength, } \\
\text { electromyographic activity, } \\
\text { pain, sleep, fatigue, } \\
\text { functional capacity }\end{array}$ & $\begin{array}{l}\text { Dynamometer, } \\
\text { Electromyography, Stanford } \\
\text { Health Assessment } \\
\text { Questionnaire, Beck } \\
\text { Depression Index }\end{array}$ & $\begin{array}{l}\text { Progressive strength } \\
\text { training is safe and } \downarrow \\
\text { impact of the syndrome on } \\
\text { the neuromuscular system, } \\
\text { perceived symptoms and } \\
\uparrow \text { functional capacity }\end{array}$ \\
\hline DELUZE et al. (1992) & 70 & $\begin{array}{l}\text { Active electroacupuncture } \\
\text { vs placebo }\end{array}$ & $\begin{array}{l}\text { Pain, number of analgesics, } \\
\text { sleep, morning stiffness, } \\
\text { general condition }\end{array}$ & $\begin{array}{l}\text { Manometer, number of } \\
\text { tablets used, VAS, sleep } \\
\text { inventory }\end{array}$ & $\begin{array}{l}\text { Electroacupuncture } \\
\text { improved all symptoms } \\
\text { of FM }\end{array}$ \\
\hline MORETTI et al. (2016) & 15 & $\begin{array}{l}\text { Pompage }+ \text { stretching }+ \\
\text { aerobic vs. stretching }+ \\
\text { exercise }\end{array}$ & Pain, fatigue, sleep & $\begin{array}{l}\text { Questionnaires: McGill, } \\
\text { Chalder's Fatigue, Sleep } \\
\text { Inventory }\end{array}$ & $\begin{array}{l}\text { Pompage + aerobic } \\
\text { exercises + stretching } \\
\text { did not show important } \\
\text { beneficial effects }\end{array}$ \\
\hline SILVA et al. (2008) & 10 & Hydrotherapy vs. TENS & $\begin{array}{l}\text { Flexibility, pain, quality of } \\
\text { life, depression }\end{array}$ & $\begin{array}{l}\text { Third finger-soil index, VAS, } \\
\text { SF-36, NHP, Beck inventory }\end{array}$ & $\begin{array}{l}\text { Hydrotherapy and TENS: } \\
\uparrow \text { physical conditioning. } \\
\text { TENS: more effective in the } \\
\text { treatment of FM }\end{array}$ \\
\hline $\begin{array}{l}\text { TAKIGUCHI et al. } \\
(2008)\end{array}$ & 20 & $\begin{array}{l}\text { Acupuncture vs. insertion } \\
\text { of needles in tender points }\end{array}$ & $\begin{array}{l}\text { Pain, sleep and quality } \\
\text { of life }\end{array}$ & VAS, inventory of sleep, FIQ & $\begin{array}{l}\text { Acupuncture improved } \\
\text { pain, sleep and quality } \\
\text { of life }\end{array}$ \\
\hline $\begin{array}{l}\text { SANTANA et al. } \\
(2010)\end{array}$ & 10 & Ai Chi vs. No intervention & Pain and quality of life & $\begin{array}{l}\text { FIQ and Sensitive Points } \\
\text { Index Scale }\end{array}$ & $\begin{array}{l}\text { Ai Chi improved pain, but } \\
\text { was unable to improve the } \\
\text { quality of life }\end{array}$ \\
\hline $\begin{array}{l}\text { HECKER et al. } \\
\text { (2011) }\end{array}$ & 25 & $\begin{array}{l}\text { Hydrokinesotherapy } \mathrm{x} \\
\text { Kinesiotherapy }\end{array}$ & Quality of life & SF-36 & $\begin{array}{l}\text { Both groups improved in } \\
\text { most SF-36 domains }\end{array}$ \\
\hline $\begin{array}{l}\text { MATSUTANI et al. } \\
(2012)\end{array}$ & 32 & $\begin{array}{l}\text { Stretching } \times \text { Aerobic } \\
\text { Exercises }\end{array}$ & $\begin{array}{l}\text { Pain, number of tender } \\
\text { points, sleep, anxiety and } \\
\text { depression }\end{array}$ & $\begin{array}{l}\text { VAS, painmeter, Post } \\
\text { Sleep Inventory, Anxiety } \\
\text { Inventory and Beck } \\
\text { Depression Scale }\end{array}$ & $\begin{array}{l}\text { It is suggested that } \\
\text { stretching be more } \\
\text { beneficial in pain in the } \\
\text { number of tender points, } \\
\text { in sleep and depression. } \\
\text { Aerobic exercise produced } \\
\text { more important effects on } \\
\text { anxiety }\end{array}$ \\
\hline $\begin{array}{l}\text { VITORINO et al. } \\
\text { (2006) }\end{array}$ & 50 & $\begin{array}{l}\text { Hydrotherapy } \\
\text { vs. Conventional } \\
\text { physiotherapy }\end{array}$ & $\begin{array}{l}\text { Quality of life and total } \\
\text { sleep time }\end{array}$ & SF-36 and sleep diary & $\begin{array}{l}\text { The hydrotherapy group } \\
\text { increased in } 1 \text { hour sleep } \\
\text { time. There was also } \\
\text { improvement in the SF- } 36 \\
\text { domains but no statistical } \\
\text { significance }\end{array}$ \\
\hline $\begin{array}{l}\text { VAYVAY et al. } \\
\text { (2016) }\end{array}$ & 45 & $\begin{array}{l}\text { Laser vs. Laser placebo vs. } \\
\text { Tapping }\end{array}$ & $\begin{array}{l}\text { Pain, trunk flexibility, } \\
\text { functional status, general } \\
\text { health and anxiety }\end{array}$ & $\begin{array}{l}\text { VAS, clinical tests for } \\
\text { flexibility, FIQ, SF-36, Beck } \\
\text { Inventory }\end{array}$ & $\begin{array}{l}\text { The laser group improved } \\
\text { pain, general health, } \\
\text { anxiety and quality of life. } \\
\text { There was an increase in } \\
\text { the flexibility of the trunk } \\
\text { of the tapping group. } \\
\text { There was a significant } \\
\text { improvement in the three } \\
\text { groups for functional status } \\
\text { and pain }\end{array}$ \\
\hline $\begin{array}{l}\text { VALENCIA et al. } \\
\text { (2009) }\end{array}$ & 15 & $\begin{array}{l}\text { Kinesioteaping + active } \\
\text { muscle training vs. } \\
\text { Mièzierès Method }\end{array}$ & $\begin{array}{l}\text { Flexibility, pain and impact } \\
\text { of disease }\end{array}$ & $\begin{array}{l}\text { Clinical tests, palpation of } \\
\text { pain points and FIQ }\end{array}$ & $\begin{array}{l}\text { Both groups showed } \\
\text { reduced disease severity } \\
\text { and improved flexibility. } \\
\text { However, there was } \\
\text { no difference between } \\
\text { baseline and follow-up } \\
\text { values of } 24 \text { weeks }\end{array}$ \\
\hline
\end{tabular}

Note: VAS: Visual Analogic Scale; FIQ: Fibromyalgia Impact Questionnaire; SF-36: Short Form Health Survey; WT6: 6-minute Walk Test; CPAC: Chronic Pain Acceptance Questionnaire; FABC: Fear Avoidance Beliefs Questionnaire; PGIC: Patient Global Impression of Change; MRT1: 1 maximum repetition test; IDATE - Inventário de Ansiedade Traço-Estado; WBV: Whole Body Vibration; TENS: Transcutaneous Electrical Nerve Stimulation; FM: Fibromyalgia; MFI - Multidimensional Fatigue Inventory; LTPAI: Leisure Time Physical Activity Instrument; HADS: Hospital Anxiety and Depression Scale; CGI: Clinical Global Impression; PGA: Patient Global Assessment; MMSE: Mini Mental State Examination; PGWB: Psychological General Well-Being; RPS: Regional Pain Score; NHP: Nottingham Health Profile; MOS: Medical Outcome Study. 
Table 1. Continued...

\begin{tabular}{|c|c|c|c|c|c|}
\hline Study & Sample & Groups & Outcomes analyzed & Evaluation instruments & Results \\
\hline $\begin{array}{l}\text { ALMEIDA et al. } \\
\text { (2003) }\end{array}$ & 17 & $\begin{array}{l}\text { Pulsed ultrasound }+ \\
\text { interferential current } \\
\text { vs. Pulsed ultrasound } \\
+ \text { inactive interference } \\
\text { current }\end{array}$ & Pain and sleep & $\begin{array}{l}\text { Modified map of the } \\
\text { body of Wisconsin and } \\
\text { VAS, Fischer's painmeter } \\
\text { and palpation of the } 18 \\
\text { painful points, in addition } \\
\text { to the Brazilian Inventory } \\
\text { of Sleep Disorders and } \\
\text { polysomnography }\end{array}$ & $\begin{array}{l}\text { Improvement in both pain } \\
\text { and sleep was observed } \\
\text { in the active intervention } \\
\text { group. However, no } \\
\text { improvement was } \\
\text { observed in the placebo } \\
\text { group }\end{array}$ \\
\hline $\begin{array}{l}\text { CALANDRE et al. } \\
\text { (2009) }\end{array}$ & 81 & $\begin{array}{l}\text { Stretching vs. Ai Chi, both } \\
\text { in the pool }\end{array}$ & $\begin{array}{l}\text { Symptomatology of FM } \\
\text { and sleep }\end{array}$ & $\begin{array}{l}\text { FIQ, Pittsburgh Sleep } \\
\text { Quality Index, o Beck } \\
\text { Depression Inventory, State } \\
\text { and Trait Anxiety Inventory } \\
\text { e o SF-12 }\end{array}$ & $\begin{array}{l}\text { Although no differences } \\
\text { were found between } \\
\text { groups, Ai Chi significantly } \\
\text { improved the symptoms } \\
\text { of fibromyalgia and sleep } \\
\text { quality, while stretching } \\
\text { only improved anxiety and } \\
\text { depression }\end{array}$ \\
\hline $\begin{array}{l}\text { GONZÁLEZ-VIEJO et al. } \\
\text { (2005) }\end{array}$ & 70 & $\begin{array}{l}\text { Sertraline vs. Ultrasound + } \\
\text { physiotherapy }\end{array}$ & $\begin{array}{l}\text { Pain, morning stiffness and } \\
\text { sleep }\end{array}$ & $\begin{array}{l}\text { VAS and questionnaire } \\
\text { MOS }\end{array}$ & $\begin{array}{l}\text { Pain, sleep, and morning } \\
\text { stiffness were significantly } \\
\text { improved in the sertraline } \\
\text { therapy group }\end{array}$ \\
\hline JOSHI et al. (2009) & 175 & $\begin{array}{l}\text { Amitriptyline vs. } \\
\text { physiotherapy (physical } \\
\text { training and aerobic } \\
\text { session) }\end{array}$ & disability & $\mathrm{FIQ}$ & $\begin{array}{l}\text { Amitriptyline therapy or } \\
\text { physical therapy is equally } \\
\text { effective in improving } \\
\text { the functional capacity of } \\
\text { individuals with FM }\end{array}$ \\
\hline $\begin{array}{l}\text { CASTRO-SANCHES et al. } \\
\text { (2011) }\end{array}$ & 86 & $\begin{array}{l}\text { Myofascial release vs. } \\
\text { simulated electrotherapy }\end{array}$ & $\begin{array}{l}\text { Pain, postural stability and } \\
\text { physical function, disease } \\
\text { severity and number of } \\
\text { tender points }\end{array}$ & $\begin{array}{l}\text { Pressure algometer, McGill } \\
\text { questionnaire, balance } \\
\text { platform, FIQ, Likert scale } \\
\text { for impression of disease } \\
\text { severity }\end{array}$ & $\begin{array}{l}\text { Myofascial release } \\
\text { techniques may be a } \\
\text { complementary therapy } \\
\text { for symptoms of pain, } \\
\text { physical function and } \\
\text { clinical severity, but do } \\
\text { not improve postural } \\
\text { stability in patients with } \\
\text { fibromyalgia syndrome. }\end{array}$ \\
\hline MOUSTAFA; DIAB, 2015 & 120 & $\begin{array}{l}\text { Multimodal program vs. } \\
\text { Multimodal program + } \\
\text { cervical manipulation }\end{array}$ & $\begin{array}{l}\text { Pain, disease impact, sleep, } \\
\text { anxiety, depression and } \\
\text { posture }\end{array}$ & $\begin{array}{l}\text { FIQ, Pain Catastrophe } \\
\text { Scale, Pittisburgh Sleep } \\
\text { Quality Index, Beck } \\
\text { Inventory }\end{array}$ & $\begin{array}{l}\text { The experimental group } \\
\text { achieved significant } \\
\text { improvement in posture, } \\
\text { QIF scores, pain, sleep, } \\
\text { depression and enasy }\end{array}$ \\
\hline
\end{tabular}

Note: VAS: Visual Analogic Scale; FIQ: Fibromyalgia Impact Questionnaire; SF-36: Short Form Health Survey; WT6: 6-minute Walk Test; CPAC: Chronic Pain Acceptance Questionnaire; FABC: Fear Avoidance Beliefs Questionnaire; PGIC: Patient Global Impression of Change; MRT1: 1 maximum repetition test; IDATE - Inventário de Ansiedade Traço-Estado; WBV: Whole Body Vibration; TENS: Transcutaneous Electrical Nerve Stimulation; FM: Fibromyalgia; MFI - Multidimensional Fatigue Inventory; LTPAI: Leisure Time Physical Activity Instrument; HADS: Hospital Anxiety and Depression Scale; CGI: Clinical Global Impression; PGA: Patient Global Assessment; MMSE: Mini Mental State Examination; PGWB: Psychological General Well-Being; RPS: Regional Pain Score; NHP: Nottingham Health Profile; MOS: Medical Outcome Study.

resources (14.2\%). (10.7\%), exercises in the WBV platform (7.1\%), dry needling (3.5), acupuncture (7.1\%), pompage $(3.5 \%)$, myofascial release $\%$ ) and cervical manipulation (3.5\%) were also investigated by the studies. It is possible to perceive that the sum of evaluated outcomes and of the physiotherapeutic interventions were superior to $100 \%$. This is due to the fact that all the studies analyzed two or more techniques and / or outcomes.

To facilitate the visualization of the studies included in this review, a table was created with more detailed information about each one (Table 1).

The present study aimed to evaluate the evidence that touches on the efficacy of physiotherapeutic approaches in patients with FM. Thus, from the meeting and critical evaluation of the clinical trials, a more effective and conscious therapeutic practice becomes possible.

In general, the treatment of this disease involves multiprofessional approaches that act in physical, pharmacological, psychological and behavioral scope ${ }^{(16)}$. More specifically, in the physical domain, it is important to emphasize the role of physiotherapy, which stands out for having a series of specific techniques that aim to control pain, improve symptomatology and maintain functional abilities ${ }^{(17)}$. As an example of these techniques is kinesiotherapy, which corresponds to a set of exercises that include stretching, strengthening and aerobic training.

Gavi et al. ${ }^{(18)}$ and Matsutani et al. ${ }^{(19)}$, showed that global stretching was more effective than aerobic and moderate 
intensity strength training in improving quality of life and sleep, as well as reducing pain symptomatology, tending numbers points and depression index. However, the studies by Moretti et al. ${ }^{(20)}$ and Sañudo et al. ${ }^{(21)}$ indicate that the association of these techniques (stretching + aerobic or stretching + strength training) is more effective than pompage or usual medical care in improving the quality of sleep, pain and fatigue, general health status and functional capacity of patients with FM.

Regarding strengthening exercises, Hakkinen et al. ${ }^{(22)}$ and Larsson et al. ${ }^{(23)}$ compared women undergoing strength training with others who received relaxation or who did not undergo any intervention, and observed that in the first group there was a significant increase in strength, reduction of pain and fatigue, improvement in electromyographic activity, depression and general health status. In addition, the results of Joshi et al. ${ }^{(24)}$ showed that the strengthening applied in a way associated with aerobic exercises has a similar effect to the use of amitriptyline and may increase the functional capacity of patients with FM.

Regarding relaxation, Cedraschi et al. ${ }^{(25)}$ observed that individuals who received this type of intervention associated with pool exercises or other solo activities, such as aerobic training, had an improvement in quality of life and physical function in the long and increased satisfaction with treatment. However, a study by Coppieters et al. ${ }^{(26)}$ showed that a single relaxation session applied alone increased the temporal summation and reduced the conditioned modulation of pain in individuals with FM. Additionally, Larsson et al. ${ }^{(23)}$ observed that the relaxation exercise is less effective than the training of resisted exercises in the improvement of FM symptomatology.

Regarding the investigation of aerobic exercises, based on our review, there was a shortage of studies evaluating it in an isolated group in an intervention group. However, when evaluated in a way associated with other therapeutic modalities, it was possible to perceive some type of improvement of these patients. Moretti et al. ${ }^{(20)}$, for example, assessed the association of stretching and aerobic exercise, observed improvement in pain, fatigue and sleep quality. But when analyzing these two techniques separately, Matsutani et al. ${ }^{(19)}$ inferred that the only clinical gain in which the aerobic overlapped the elongation was in relation to the level of anxiety.

Another widely used method in the treatment of FM is hydrotherapy or aquatic physiotherapy, which consists in the performance of therapeutic exercises in a heated swimming pool ${ }^{(27)}$. Vitorino et al. ${ }^{(28)}$ demonstrated that the method was equally effective when compared to conventional physiotherapy in terms of improvement in quality of life and sleep.

According to Hecker et al. ${ }^{(27)}$, hydrokinesitherapy and kinesiotherapy showed a significant improvement in most of the aspects addressed by the SF-36 questionnaire. Thus, it is suggested by the authors that aquatic kinesiotherapy promotes a muscular relaxation favorable for the improvement of the quality of life. However, it is not the main factor to reduce the symptomatology, since the technique in soil also provided beneficial effects for the promotion of the well-being of these individuals.

In addition, data from the study by Calandre et al. ${ }^{(29)}$ point to the existence of improvement in quality of life and anxiety level in patients submitted to the Ai Chi method (active relaxation method in the aquatic environment) or to stretching, without significant difference between the interventions. However, the study by Santana et al. ${ }^{(14)}$ shows that the Ai Chi method improved pain, but did not present significant results on quality of life. However, when compared to health education, Mannerkorpi et al. ${ }^{(30)}$ observed that hydrotherapy presented better results in reducing pain and FIQ scores and increased physical fitness. In addition, it could be seen from the study by Silva et al. ${ }^{(31)}$ that hydrotherapy was shown to be less effective than Transcutaneous Electrical Nerve Stimulation (TENS) analgesia in improving pain and both interventions were equally beneficial in quality of life.

It is also important to emphasize the practical use of electric, thermal and phototherapy resources in the therapeutic management of people with FM. Transcutaneous Electrical Nerve Stimulation, according to the findings of Carbonario et al. ${ }^{(32)}$, presented reduction of pain, fatigue, morning stiffness, anxiety and depression and improvement in work performance. Regarding Transcranial Direct Current Stimulation, Fregni et al. ${ }^{(33)}$ observed a reduction in pain and improvement in quality of life in patients with FM.

Regarding ultrasound, the study by Almeida et al. ${ }^{(34)}$ that evaluated the combination of this feature with interferential current showed improvement of pain in this group compared to the sham group. However, the efficacy of the combination of sleep therapy with conventional physiotherapy was lower when compared to the use of sertraline in pain, morning stiffness and sleep quality, according to the results presented by Gonzalez-Viejo et al. ${ }^{(35)}$.

Vayvay et al. ${ }^{(36)}$, in turn, conducted a clinical trial that used another feature, laser therapy, compared to kinesio taping and found that there was a significant improvement in pain severity during activities, anxiety level and general health by application of the laser, while in the taping group there was an increase in trunk flexibility. In the post-intervention, it was also possible to observe that in both groups pain reduction during the night and improvement of functional status occurred. Therefore, the authors suggested that both kinesio and laser applications generate a similar effect on the parameters in patients with FM, so the first method could be preferred instead of laser application to a rehabilitation program.

Although it was still a question of bandages, it was possible to observe that needle application improved pain measurements and, with respect to the mobility of the spine, the two interventions induced similar results. Another method involving the use of needles, acupuncture, proved to be 
effective, according to the study Targino et al. ${ }^{(38)}$ in improving pain and quality of life; besides the reduction in the number of analgesic medications, sleep quality, morning stiffness and general health status, as seen by Deluse et al. ${ }^{(39)}$. Targino et al. ${ }^{(38)}$ also observed that the effects of acupuncture may be higher than that of antidepressants in the long term.

Regarding the techniques of manual therapy, the results of Moretti et al. ${ }^{(20)}$ suggest that pompage as complementary therapy to aerobic and stretching exercises does not present important beneficial effects for women with fibromyalgia, since the other techniques cited induced similar improvements or higher in the pain of these patients. The study by Castro-Sanches et al. ${ }^{\left({ }^{(4)}\right)}$ concluded that myofascial release may be a useful complementary therapy to improve pain, physical function and severity. However, the technique was not able to interfere in the postural stability of FM patients. In addition, Moustafa and Diab(41) suggest that the addition of cervical manipulation in subjects with FM and cervical dysfunction may improve posture, pain, sleep, anxiety, depression, and disease impact.

Finally, Whole Body Vibration (WBV) or Whole Body Vibration platform exercises, according to the findings of Sañudo et al. ${ }^{(42)}$ and Gusi et al. ${ }^{(43)}$, showed to be effective in improving the balance in women with FM, increasing by up to $36 \%$.

It is possible to identify that the included trials evaluated a variety of physiotherapeutic approaches aimed at the treatment of FM patients, with pain and quality of life being the outcomes most studied by the researchers. Also noteworthy is the wide use of questionnaires and scales for the evaluation of these individuals. It is important to emphasize the heterogeneity of the techniques regarding the intensity, duration and forms of application, and this must be carefully analyzed by the professional in the clinical scope.

Therefore, the results of the present review, with a focus on the techniques and their effects, allowed the compilation of evidence and provided a subsidy for the decision-making of physiotherapists in the elaboration of treatment protocols more effective and scientifically based.

\section{CONCLUSION}

Evidence supports the use of physiotherapy in the treatment of patients with FM, since in all studies the applied techniques showed some benefit in relation to the signs and symptoms of the disease, with the exception of progressive relaxation and pompage that did not show beneficial effects in these patients. It is suggested, therefore, that the physiotherapeutic techniques are quite effective in treating the symptomatology and the physical and functional consequences of the individual with FM.

\section{AUTHORS' CONTRIBUTIONS}

YTP- writing the manuscript; MCS and TABA- search and selection of studies; RSS- translation and final revision of the text; CAAL- elaboration of the work protocol and final revision of the text.

\section{CONFLICT OF INTEREST}

nothing to declare.

\section{AUTHORS DETAILS}

${ }^{2}$ Programa de Pós-graduação em Saúde Coletiva, Faculdade de Ciências da Saúde do Trairí, Universidade Federal do Rio Grande do Norte, Santa Cruz, Rio Grande do Norte, Brasil.

\section{REFERENCES}

1. Talotta R, Bazzichi L, Di Franco M, Casale R, Batticciotto A, Gerardi MC, et al. One year in reviwe 2017: fibromyalgia. Clin Exp Rheumatol. 2017;35 (Suppl. 105):6-12.

2. Ramiro FS, Lombardi Júnior I, Silva RCB, Montesano FT, Oliveira NRC, Diniz REAS, et al. Investigação do estresse, ansiedade e depressão em mulheres com fibromialgia: um estudo comparativo. Rev. Bras. Reumatol. 2014;54(1):27-32.

3. Yunus M, Masi AT, Calabro JJ, Miller KA, Feigenbaum SL. Primary fibromyalgia (fibrositis): Clinical study of 50 patients with matched normal controls. Semin. Arthritis. Rheum. 1981;11(1):151-171.

4. Inanici F, Yunus MB. History os fibromialgya: past to presente. Curr Pain Headache Rep. 2004;8(5):369-378.

5. Marques AP, Santo ASE, Berssaneti AA, Matsutani LA, Yuan SLK. Prevalence of fibromyalgia: literature review update. Rev. Bras. Reumatol. 2017;57(4):356-363.

6. Cavalcante AB, Sauer JF, Chalot SD, Assumpção A, Lage LV, Matsutani $\mathrm{LA}$, et al. The prevalence of fibromyalgia: a literature review. Rev. Bras. Reumatol. 2006;46(1):40-48.

7. Martinez JE, Casagrande PM, Ferreira PPR, Rossato BLG. Correlação entre variáveis demográficas e clínicas, e a gravidade da fibromialgia. Rev. Bras. Reumatol. 2013;53(6):460-463.

8. Heymann RE, Paiva ES, Martinez JE, Helfenstein Júnior M, Rezende MC, Provenza JR, et al. New guidelines for the diagnosis of fibromyalgia. Rev. Bras. Reumatol. 2017;57(2):467-476.

9. Araújo ALPK, Pilares IC, Araújo MIPK, Novo NF, Cadaval RAM, Martinez JE. A associação fibromialgia e lúpus eritematoso sistêmico altera a apresentação e a gravidade de ambas as doenças? Rev. Bras. Reumatol. 2015;55(1):37-42.

10. Góes SM, Leite N, Souza RM, Homann D, Osiecki ACV, Stefanello JMF, et al. Características da marcha de mulheres com fibromialgia: um padrão prematuro de envelhecimento. Rev. Bras. Reumatol. 2014;54(5):335-341.

11. Beber JSS, Kuped E, Berber SC. Prevalência de depressão e sua relação com a qualidade de vida em pacientes com síndrome da fibromialgia. Rev. Bras. Reumatol. 2005;45(2):47-54.

12. Giusti EM, Castelnuevo G, Molinari E. Differences in multidisciplinar and interdisplinary treatment programs for fibromyalgia: a mapping review. Pain. Res. Manag. 2017; 2017: 7261468.

13. Santana JS, Almeida APG, Brandão PMC. Os efeitos do método Ai Chi em pacientes portadores da síndrome fibromiálgica. Cien saúde coletiva. 2010;15(supl. 1):1433-1438.

14. van Eijk-Hustings $Y$, Kroese M, Tan F, Boonen A, Bessems-Beks M, Landewé R. Challenges in demonstrating the effectiveness of multidisciplinary treatment on quality of life, participation and health care utilisation in patients with fibromyalgia: a randomised controlled trial. Clin Rheumatol. 2013 Feb;32(2):199-209. 
15. Keel PJ, Bodoky C, Gerhard U, Müller: Comparison of Integrated Group Therapy and Group Relaxation Training for Fibromyalgia. The Clinical Journal of Pain 14: 232-8, 1998.

16. Lorena SB, Lima MCC, Ranzolin A, Duarte ALBP. Efeitos dos exercícios de alongamento muscular no tratamento da fibromialgia: uma revisão sistemática. Rev Bras Reumatol. 2015; 55(2): 167-173.

17. Batista JS, Borges AM, Wibelinger LM. Tratamento fisioterapêutico na síndrome da dor miofascial e fibromialgia. Rev Dor. 2012; 13(2):170-174.

18. Gavi MB, Vassalo DV, Amaral FT, Macedo DC, Gava PL, Dantas EM, et al. Strengthening exercises improve symptoms and quality of life but do not change autonomic modulation in fibromyalgia: a randomized clinical trial. PLoS One. 2014; 9(3):e90767.

19. Matsutani LA, Assumpção A, Marques AP. Exercícios de alongamento muscular e aeróbico no tratamento da fibromialgia: estudo piloto. Fisioter Mov. 2012; 25(2):411-418.

20. Moretti EC, De Araújo MEMV, Campos AG, Santos LRH, De Araújo MGR, Tenório AS. Efeitos da pompage associada ao exercício aeróbico sobre dor, fadiga e qualidade do sono em mulheres com fibromialgia: um estudo piloto. Fisioter Pesqui. 2016; 23(3):227-233.

21. Sañudo B, Galiano D, Carrasco L, de Hoyo M, McVeigh JG. Effects of a prolonged exercise program on key health outcomes in women with fibromyalgia: a randomized controlled trial. J Rehabil Med. 2011; 43(6):521-6.

22. Häkkinen A, Häkkinen K, Hannonen P, Alen M. Strength training induced adaptations in neuromuscular function of premenopausal women with fibromyalgia: comparison with healthy women. Ann Rheum Dis. 2001; 60(1):21-6.

23. Larsson A, Palstam A, Löfgren M, Ernberg M, Bjersing J, Bileviciute-Ljungar I, et al. Resistance exercise improves muscle strength, health status and pain intensity in fibromyalgia--a randomized controlled trial. Arthritis Res Ther. 2015;17:161.

24. Joshi MN, Joshi R, Jain AP. Effect of amitriptyline versus physiotherapy in management of fibromyalgia syndrome: what predicts a clinical benefit? J Postgrad Med. 2009; 55(3):185-189.

25. Cedraschi C, Desmeules J, Rapiti E, Baumgartner E, Cohen P, Finckh A, et al. Fibromyalgia: a randomised, controlled trial of a treatment programme based on self management. Ann Rheum Dis. 2004; 63(3):2906.

26. Coppieters I, Cagnie B, Nijs J, van Oosterwijck J, Danneels L, De Pauw $\mathrm{R}$, et al. Effects of Stress and Relaxation on Central Pain Modulation in Chronic Whiplash and Fibromyalgia Patients Compared to Healthy Controls. Pain Physician. 2016; 19(3):119-30.

27. Hecker CD, Melo C, Tomazoni SS, Martins RABL, Leal Júnior ECP. Análise dos efeitos da cinesioterapia e da hidrocinesioterapia sobre a qualidade de vida de pacientes com fibromialgia - um ensaio clínico randomizado. Fisioter Mov. 2011; 24(1):57-64.

28. Vitorino DF, Carvalho LB, Prado GF. Hydrotherapy and conventional physiotherapy improve total sleep time and quality of life of fibromyalgia patients: randomized clinical trial. Sleep Med. 2006; 7(3):293-296.

29. Calandre EP, Rodriguez-Claro ML, Rico-Villademoros F, Vilchez JS, Hidalgo J, Delgado-Rodriguez A. Effects of pool-based exercise in fibromyalgia symptomatology and sleep quality: a prospective randomised comparison between stretching and Ai Chi. Clin Exp Rheumatol. 2009; 27(5 Suppl 56):S21-S28
30. Mannerkorpi K, Nordeman L, Cider A, Jonsson G. Does moderate-tohigh intensity Nordic walking improve functional capacity and pain in fibromyalgia? A prospective randomized controlled trial. Arthritis Res Ther. 2010;12(5):R189.

31. Silva TFG, Suda EY, Marçulo CA, Paes FHS, Pinheiro GT. Comparação dos efeitos da estimulação elétrica nervosa transcutânea e da hidroterapia na dor, flexibilidade e qualidade de vida de pacientes com fibromialgia. Fisioter Pesqui. 2008; 15(2):118-124.

32. Carbonario F, Matsutani LA, Yuan SL, Marques AP. Effectiveness of highfrequency transcutaneous electrical nerve stimulation at tender points as adjuvant therapy for patients with fibromyalgia. Eur J Phys Rehabil Med. 2013; 49(2):197-204.

33. Fregni F, Gimenes $R$, Valle AC, Ferreira MJ, Rocha RR, Natalle $L$, Bravo $R$, Rigonatti SP, Freedman SD, Nitsche MA, Pascual-Leone A, Boggio PS. A randomized, sham-controlled, proof of principle study of transcranial direct current stimulation for the treatment of pain in fibromyalgia. Arthritis Rheum. 2006; 54(12):3988-3998.

34. Almeida TF, Roizenblatt S, Benedito-Silva AA, Tufik S. The effect of combined therapy (ultrasound and interferential current) on pain and sleep in fibromyalgia. Pain. 2003; 104(3):665-672.

35. Gonzalez-Viejo MA, Avellanet M, Hernandez-Morcuende MI. A comparative study of fibromyalgia treatment: ultrasonography and physiotherapy versus sertraline treatment. Ann Phys Rehabil Med. 2005; 48(8):610-615.

36. Vayvay ES, Tok D, Turgut E, Tunay VB. The effect of laser and taping on pain, functional status and quality of life in patients with fibromyalgia syndrome: a placebo-randomized controlled clinical trial. J Back Musculoskelet Rehabil. 2016; 29(1):77-83.

37. Castro-Sanchez AM, Garcia-Lopez H, Mataran-Penarrocha GA, FernandezSanchez M,Fernandez-Sola C, Granero-Molina J, Aguilar-Ferrandiz ME. Effects of Dry Needling on Spinal Mobility and Trigger Points in Patients with Fibromyalgia Syndrome. Pain Physician. 2017; 20(2):37-52.

38. Targino RA, Imamura M, Kaziyama HH, Souza LP, Hsing WT, Furlan AD, Imamura ST, Azevedo Neto RS. A randomized controlled trial of acupuncture added to usual treatment for fibromyalgia. J Rehabil Med. 2008 Jul;40(7):582-8.

39. Deluze C, Bosia L, Zirbs A, Chantraine A, Vischer TL. Electroacupuncture in fibromyalgia: results of a controlled trial. BMJ. $1992 \mathrm{Nov}$ 21;305(6864):1249-52.

40. Castro-Sanches AM, Matarán-Peñarrocha GA, Arroyo-Morales M, Saavedra-Hernández $M$, Fernández-Sola $C$, Moreno-Lorenzo C. Effects of myofascial release techniques on pain, physical function, and postural stability in patients with fibromyalgia: a randomized controlled trial. Clin Rehabil. 2011;25(9):800-813.

41. Moustafa IM, Diab AA. The addition of upper cervical manipulative therapy in the treatment of patients with fibromyalgia: a randomized controlled trial. Rheumatol Int. 2015 Jul;35(7):1163-74.

42. Sanudo B, Carrasco L, de Hoyo M, Olivia-Pascual-Vaca Á, RodríguesBlanco $C$. Changes in body balance and functional performance following whole-body vibration training in patients with fibromyalgia syndrome: a randomized controlled trial. J Rehabil Med. 2013 Jul;45(7):678-84.

43. Gusi N, Parraca JA, Olivares PR, Leal A, Adsuar JC. Tilt vibratory exercise and the dynamic balance in fibromyalgia: A randomized controlled trial. Arthritis Care Res. 2010;62(8):1072-8. 